\title{
A putative resistant DNA marker for wool yellowing susceptibility in sheep
}

\author{
M.V. Benavides, S. Damak and A.P. Maher
}

\begin{abstract}
\section{INTRODUCTION}

Clean wool colour is an important economic trait in the sheep industry. Yellow colour wools are penalised because it affects industrial versatility as far as dyeing is concerned. Clean wool colour expression is known to be genetically and, more importantly, environmentally affected, thus results from direct selection would cause variable responses. Direct selection against clean wool colour would be particularly difficult at low-challenging environmental conditions where the identification of resistant sheep could be biased with false-positive phenotypes, causing susceptible sheep to be selected along with resistant sheep, making selection against colour ineffective.

To overcome environmental influences on the expression of clean wool colour, the potential of molecular markers was investigated in order to allow genotypic identification of resistant and susceptible sheep to wool yellowing.

The aim of this experiment was to investigate the existence of a DNA marker for susceptibility to wool yellowing by screening groups of resistant and susceptible sheep by means of the differential display technique.
\end{abstract}

An Australian Merino flock was screened for low (resistant) and high (susceptible) yellow predictive colour (YPC) breeding values in order to compare extreme individuals using the differential display of mRNA technique. One differentially expressed cDNA band was visualised only in the resistant group. This band showed no identity with the DNA sequences of public databases; however, they showed short homologies with three database sequences related to transmembrane signalling functions. The use of these candidate genes as DNA markers needs to be confirmed against sheep with a wide range of susceptibility to wool yellowing to verify the results.

\section{MATERIAL AND METHODS}

Animals

Australian Merino sheep data were collected from a private property (Omarama Station, Omarama, Central Otago, New Zealand). Records on 668 offspring from 22 sires were collected over a 4-year period. In consecutive years the total numbers of sires and offspring were 6 and 137, 6 and 153, 5 and 186, and 9 and 192, respectively, with an average of 25 progeny per sire.

Midside skin and wool samples (accepted under ethical approval) were taken at shearing time. Yellow predictive colour (YPC) score was determined according to Wilkinson
(1981). Greasy fleece weight (GFW), clean fleece weight (CFW), scouring yield percentage (Yield), and mean fibre diameter (MFD) were also recorded at shearing.

\section{Statistical analysis}

Data were analysed using the general linear models (GLM) of SAS package V6 (SAS, 1990) to determine which were the significant fixed effects. Year of birth and sex were used as fixed effects and sire was included as a random effect.

The model fitted to each variable was:

$$
\mathrm{Y}_{i j k l}=\mu+\mathrm{yob}_{i}+\mathrm{x}_{j}+\mathrm{s}_{k}+\mathrm{e}_{i j k l}
$$

where $\mathrm{Y}_{i j k l}=$ record of the $l$ th individual; $\mu=$ population mean; yob $_{i}=$ year of birth; $\mathrm{x}_{j}=\mathrm{sex} ; \mathrm{s}_{k}=$ sire, and $\mathrm{e}_{i j k l}=$ error of the lth individual.

Heritability of YPC was estimated from variance components calculated using restricted maximum likelihood (REML) procedures with the average information restricted maximum likelihood (AIREML) statistical package (Johnson and Thompson, 1995) being used for the analyses.

\section{Selection of individuals}

The strategy used to select the animals for the differential display (DD) experiment was the same as that used by Lander and Botstein (1989), which was based on selecting individuals from the two YPC score extremes within the population. Ten unrelated sheep were selected based on YPC score's breeding values (BV) out of the 668 Merino sheep. The resistant (lowest YPC score's BVs) and susceptible (highest YPC score's BVs) groups contained each 5 sheep.

The YPC score's breeding values corrected for the significant $(\mathrm{P}<0.01)$ fixed effects of sex and year of birth were calculated using the following formulae: 


$$
\mathrm{BV}_{i j k}=\left(\mathrm{YPC}_{i j k}-\mathrm{YPCc}_{i j}\right) * \mathrm{~h}^{2}
$$

where $\mathrm{BV}_{i j k}=$ the breeding value of the sheep of $_{\text {of }}$ the $\operatorname{sex}_{j}$ in the year $;$ YPC $_{i j k}=$ YPC score of the sheep ${ }_{k}$ of the $\operatorname{sex}_{j}$ in the year $i$ YPCc $_{i j}=$ YPC correction for $\operatorname{sex}_{j}$ and year ${ }_{i}$, and $\mathrm{h}^{2}=$ heritability of YPC for the current flock (calculated as $\mathrm{h}^{2}=$ $0.25 \pm 0.13)$.

$$
\mathrm{YPCc}_{i j}=\mathrm{LSM}_{i j}-\frac{\left(\sum \mathrm{YPC}_{i j k}\right)}{\mathrm{n}}
$$

where $\mathrm{LSM}_{i j}=$ least square mean of YPC for the $\operatorname{sex}_{j}$ in the year $_{i} ; \mathrm{n}=$ total number of animals in the flock over years and sexes.

Averages of both groups, low YPC score's BV (resistant) and high YPC score's BV (susceptible) are presented in Table I.

The animals had midside wool samples taken at hogget age and then again at adult age, to double check their YPC scores. Selection of the animals for DD analyses was based on adult YPC scores. Skin samples were also taken from the midside patch during adult wool sampling.

\section{TECHNIQUES}

\section{RNA extraction}

Whole skin samples were homogenised with a Polytron homogeniser (Kinematica GmbH, Luzern, Switzerland) at speed 7 and RNA was extracted with TRIzol (Life Technologies, Auckland) according to the manufacturer's instructions. RNA pellets were dissolved in $20 \mu \mathrm{l}$ DEPCtreated water and the RNA concentration was measured at $260 \mathrm{~nm}\left(\mathrm{~A}_{260} \mathrm{~nm}\right)$ in a spectrophotometer. RNA samples were run in $0.8 \%$ agarose gel in $1 \mathrm{X}$ TBE buffer to check whether RNA was degraded or intact.

RNA samples were DNA decontaminated by digestion at $37^{\circ} \mathrm{C}$ for $30 \mathrm{~min}$ with $10 \mathrm{U}$ DNase I RNase-free (Boehringer Mannheim), 1X DNase I buffer and $20 \mathrm{U}$ RNase inhibitor (Boehringer Mannheim), followed by $\mathrm{phenol} / \mathrm{chloroform}$ extraction, and ethanol precipitation. RNA concentrations were measured at $\mathrm{A}_{260} \mathrm{~nm}$ and RNA integrity was checked again on $0.8 \%$ agarose gel.

DNA-free RNA $(0.2 \mu \mathrm{g})$ was transcribed to complementary DNA (cDNA) in a total reaction volume of $20 \mu \mathrm{l}$, with $20 \mu \mathrm{M} 4 \mathrm{dNTP}$ (dATP, dGTP, dTTP, dCTP), 1X reverse transcriptase buffer, $10 \mathrm{mM}$ DTT, and $1 \mu \mathrm{M}$ 14-mer oligo (dT) primer (OP) (Table II). The RNA reactions were incubated at $65^{\circ} \mathrm{C}$ for $5 \mathrm{~min}$ to allow RNA denaturing, followed by a second incubation at $37^{\circ} \mathrm{C}$ for $10 \mathrm{~min}$ to allow primer annealing. Ten units of reverse transcriptase (RT) from Moloney murine leukemia virus (MoMuLV; Life Technologies, Auckland) were added and the reaction was incubated at $37^{\circ} \mathrm{C}$ for $50 \mathrm{~min}$, for RNA reverse transcription into cDNA, followed by a final incubation at $95^{\circ} \mathrm{C}$ for 5 min to inactivate the enzyme. The negative controls were the reaction without reverse transcriptase and the reaction without RNA.

PCR amplification of cDNA was conducted using $2 \mu \mathrm{l}$ of the RT product in a $20-\mu \mathrm{l}$ reaction mixture containing $2 \mu \mathrm{M}$ 4dNTP (dATP, dGTP, dTTP, dCTP), 1X PCR buffer, $0.2 \mu \mathrm{M} 10$-mer arbitrary primer (AP) (Table II), $1 \mu \mathrm{M}$ 14-mer oligo (dT) primer (OP) (Table II), $0.1 \mu \mathrm{Ci}$ $\alpha^{32} \mathrm{PdCTP}$, and $1 \mathrm{U}$ Taq DNA polymerase (Boehringer Mannheim). Forty microlliters of mineral oil was placed on the top of the reaction to avoid evaporation.

Four different oligo (dT) primers (Table II) were used in the current experiment, generating 4 different species of mRNA in the RT step. PCR amplification was performed using either an arbitrary primer and the oligo (dT) primer used for RT (OP-AP) or two different arbitrary primers (AP-AP) (Table II). The use of AP and OP primers in cDNA amplification has been described in Liang and Pardee (1992).

The PCR conditions were: 40 cycles of denaturation at $94^{\circ} \mathrm{C}$ for $30 \mathrm{~s}$, annealing of primers at $40^{\circ} \mathrm{C}$ for 2 min, extension at $72^{\circ} \mathrm{C}$ for $30 \mathrm{~s}$ followed by one final extension cycle at $72^{\circ} \mathrm{C}$ for 5 min (Liang and Pardee, 1994)

PCR products $(3.2 \mu l+2 \mu l$ formamide loading dye $)$ were run in a $6 \%$ polyacrylamide denaturing sequencing gel containing $7 \mathrm{M}$ urea in $1 \mathrm{X}$ TBE buffer at $2000 \mathrm{~V}$ for $2.5 \mathrm{~h}$. The gel was transferred to Whatmann No. 3 filter paper, vacuum dried at $80^{\circ} \mathrm{C}$ for $1 \mathrm{~h}$ and exposed to X-ray film (Kodak) for 2 days. The filter paper was stapled to

Table I - Hogget yellow predictive colour (YPC) scores and breeding values (BV) of individuals used in the experiment.

\begin{tabular}{|lcccc|}
\hline Group & Mean YPC & YPC range & Mean BV & BV range \\
\hline Resistant & 2.6 & $1-3$ & -0.560 & -0.604 to -0.548 \\
Susceptible & 6.4 & $6-8$ & +0.660 & +0.646 to +0.701 \\
\hline
\end{tabular}

Table II - Oligo (dT) primer (OP) sequence used in the reverse transcriptase (RT) step and oligo (dT) and arbitrary primer

\begin{tabular}{|c|c|c|c|c|}
\hline Steps & $\begin{array}{c}\text { Oligo }(\mathrm{dT}) \\
\text { primers }\end{array}$ & Sequences & $\begin{array}{c}\text { Arbitrary } \\
\text { primers }\end{array}$ & Sequences \\
\hline \multirow[t]{4}{*}{ RT } & OP2 & $5^{\prime} \mathrm{T}_{12} \mathrm{AG} 33^{\prime}$ & & \\
\hline & OP 3 & $5^{\prime} \mathrm{T}_{12} \mathrm{AC} 3{ }^{\prime}$ & & \\
\hline & $\mathrm{OP} 4$ & $5^{\prime} \mathrm{T}_{12} \mathrm{AT} 3{ }^{\prime}$ & & \\
\hline & OP 5 & $5^{\prime} \mathrm{T}_{12} \mathrm{GA} 3^{\prime}$ & & \\
\hline \multirow[t]{7}{*}{ PCR } & OP2 & $5^{\prime} \mathrm{T}_{12} \mathrm{AG} 3^{\prime}$ & GT 01 & 5' AGTTCGTCTG3' \\
\hline & OP 3 & $5^{\prime} \mathrm{T}_{12} \mathrm{AC} 3^{\prime}$ & GT 03 & 5' CTCGGTACAC 3' \\
\hline & $\mathrm{OP} 4$ & $5^{\prime} \mathrm{T}_{12} \mathrm{AT} 3{ }^{\prime}$ & GT 06 & 5' ATGTGGTGGT3' \\
\hline & OP 5 & $5^{\prime} \mathrm{T}_{12} \mathrm{GA} 3^{\prime}$ & GT 09 & 5' TCTGCCGTGA 3' \\
\hline & & & $267 / 2$ & 5' ACATAGACGG3 \\
\hline & & & $267 / 4$ & 5' GGATGTCGAA 3 \\
\hline & & & $371 / 1$ & 5' GATAACGCAC 3 \\
\hline
\end{tabular}
sequences used in the PCR step. 
the X-ray film and hole punched to allow cDNA recovery from the polyacrylamide gel after candidate genes had been identified in the autoradiograph.

The molecular weight marker used for polyacrylamide gels was the promoter region of the rabbit uteroglobin gene inserted in the EcoRI site of pBluescript $\mathrm{KS}(+)$ (DeMayo et al., 1991) digested with BanI (Boehringer Mannheim) and end labelled with $\alpha^{32} \mathrm{P}-\mathrm{dCTP}$ using the Klenow fragment of DNA polymerase I (Amersham, Buckinghamshire, UK). The digestion generated DNA fragments of 1736 bp, 1231 bp, 1097 bp, 834 bp, 460 bp, 426 bp, $218 \mathrm{bp}, 142 \mathrm{bp}$ and $76 \mathrm{bp}$.

The differentially expressed cDNA bands, hereafter termed cDNA, were cut from the polyacrylamide gel with a scalpel blade. The cDNA was eluted from the gel in $100 \mu \mathrm{l} \mathrm{TE}$ buffer, $\mathrm{pH} 7.6$, at $37^{\circ} \mathrm{C}$ for $12 \mathrm{~h}$, followed by incubation at $100^{\circ} \mathrm{C}$ for $15 \mathrm{~min}$. To the TE buffer were added $3 \mathrm{M}$ sodium acetate to a final concentration of 0.3 $\mathrm{M}, 10 \mathrm{mg} / \mathrm{ml}$ glycogen to a final concentration of $0.5 \mu \mathrm{g}$, and $400 \mu \mathrm{l} 100 \%$ ethanol to precipitate the DNA. The samples were incubated at $-70^{\circ} \mathrm{C}$ for $30 \mathrm{~min}$ and then centrifuged at 14,000 rpm for $10 \mathrm{~min}$, after which the DNA pellets were washed with $85 \%$ ethanol and dissolved in $20 \mu \mathrm{l}$ of sterile water.

PCR amplification of the recovered cDNA band was done in a 40- $\mu$ l reaction mixture using the same PCR conditions and final reaction concentrations as previously described, except for the absence of the radioisotope and the concentration of the dNTPs being $20 \mu \mathrm{M}$. These bands were subcloned in the pCR II vector (TA Cloning kit, Invitrogen, San Diego, CA). Transformation was done using $E$. coli $\mathrm{DH} 5 \alpha$ competent cells using blue and white selection. A modified alkaline lysis/PEG precipitation protocol (PRISM Ready Reaction DyeDeoxy Terminator Cycle Sequencing Kit Protocol, Perkin-Elmer Corporation) was used. DNA samples (200 $\mathrm{ng} / \mu \mathrm{l}$ each) were sequenced in the automated sequencing facility of Auckland University using M13 and reverse M13 primers.

The forward and reverse directions of the cloned sequences were checked for homology using the DNAMAN for Windows programme Version 2.5 (Lynnon BioSoft, Quebec). The cloned cDNA sequences were then compared with DNA sequences from international databases in order to search for homology with known DNA sequences by using the BLASTN programme (Altschul et al., 1990).

Those DNA sequences identified by the BLASTN GenBank and TIGR searches as having short homologies with the cloned sequences were searched in the ENTREZ Nucleotide query browser provided by the National Center for Biotechnology Information [http://www3.ncbi. nlm.nih.gov/htbin-post/Entrez/] in order to identify their protein coding sequences (CDS).

The DNA sequences with CDS present within the region of homology between the cloned sequences and the DNA sequences were then searched in the PC/GENE pro- gram Release 6.8 under the PROSITE option (Bairoch, 1993) to find the likely function of the protein.

\section{RESULTS}

The Merino flock studied presented a wide range of YPC scores, from 1 to 10 , and averaged $4.47 \pm 1.38$. Twenty-eight percent of the animals showed YPC scores between 6 and 10 (Table III). Sheep with YPC scores of 6 and above were considered to be highly susceptible to wool yellowing. The genetic and environmental variances of YPC scores observed for the Merino flock were 0.50 and 1.91 (not tabulated), respectively.

The two groups of sheep selected because of their extreme breeding values for YPC scores did not differ significantly $(\mathrm{P} \geq 0.05)$ for GFW, CFW, Yield, or MFD. The only apparent significant difference $(\mathrm{P}<0.001)$ was for YPC and visual wool colour assessment. The analysis of variance of YPC scores showed that the score averages significantly differed between years of birth $(\mathrm{P}<0.001)$ and sexes $(\mathrm{P}<0.01)$, with females presenting higher YPC scores than males.

The heritability of YPC, as estimated by the sire model, was found to be $0.25 \pm 0.13$, and was used to calculate YPC breeding values from which the resistant and the susceptible groups of sheep were selected to participate in the current experiment.

The 4 mRNA species generated by reverse transcriptase using 4 different OP primers (Table II) were used in 53 PCR rounds with different OP-AP primer and APAP primer combinations. An average of $52 \mathrm{cDNA}$ fragments with sizes varying between $1700 \mathrm{bp}$ and $30 \mathrm{bp}$ were observed per gel. Fifty percent of the bands amplified were fragments shorter than $600 \mathrm{bp}$. Only $8.6 \%$ of the cases showed amplified bands with sizes greater than $1500 \mathrm{bp}$.

The majority of the differential display results $(92.5 \%)$ showed a similar banding pattern between the lanes, i.e., between individuals, with only $7.5 \%$ of the differential displays showing a wide variability of band patterns between lanes. This pattern occurred both when OP primers and when AP primers were used as 3'-end primers at the PCR step, being $10.5 \%$ of the OP-AP combinations and $5.88 \%$ of the AP-AP combinations.

A differentially displayed band was amplified with the primer combinations: OP3-GT09, a 232-bp long cDNA band expressed in four of the five resistant individuals (hereafter termed cDNA\#R; Figure 1).

Table III - Yellow predictive colour (YPC) and visual score frequencies for Merinos.

\begin{tabular}{|c|c|c|c|c|c|c|c|c|c|c|}
\hline $\begin{array}{l}\text { Score } \\
\text { frequencies }(\%)\end{array}$ & 1 & 2 & 3 & 4 & 5 & 6 & 7 & 8 & 9 & 10 \\
\hline YPC & 1.8 & 9.1 & 19.2 & 21.0 & 20.8 & 18.6 & 7.2 & 1.3 & 0.9 & 0.1 \\
\hline Visual score & 0.6 & 6.6 & 30.5 & 34.7 & 13.7 & 9.8 & 3.6 & 0.5 & 0 & 0 \\
\hline
\end{tabular}




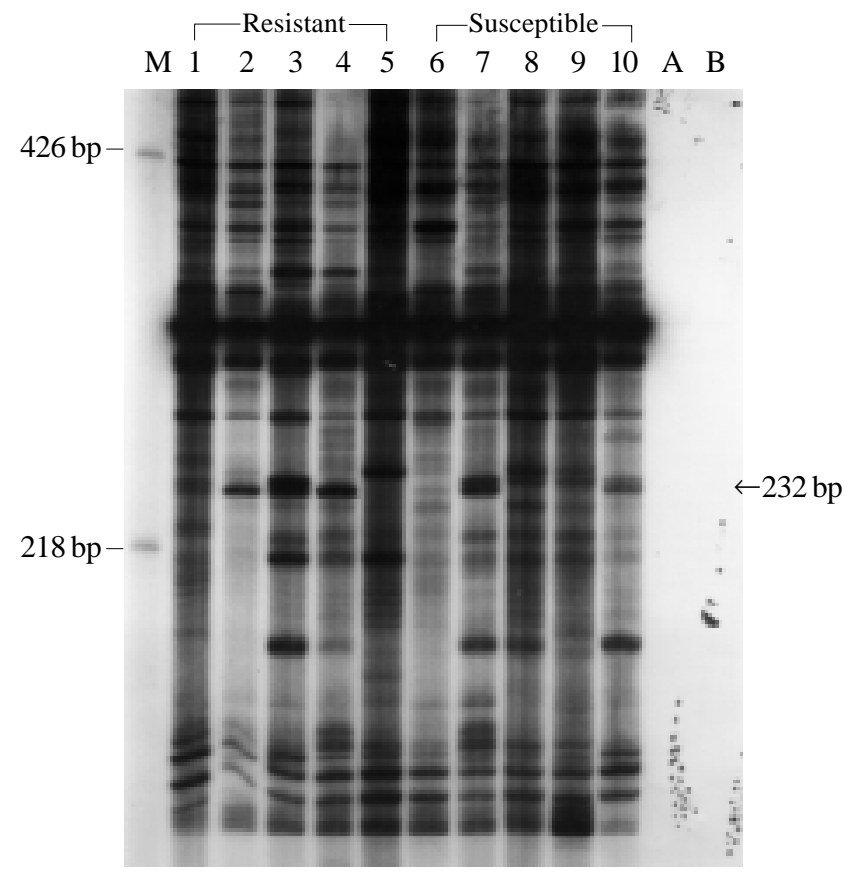

Figure 1 - Differential display of mRNA using primers OP3 and GT9. Lane M: Molecular weight marker; lanes 1-5, resistant sheep; lanes 6-10, susceptible sheep; lane A - control (no RNA) and lane B - control (no reverse transcriptase). The 232-bp band is present only in the resistant group. The arrow shows the differentially displayed band corresponding to cDNA\#R.

\section{Sequences}

The forward and reverse sequences of cDNA\#R are presented in Figure 2. The forward sequence was sequenced using M13 primer and the reverse sequence with the M13 reverse primer.

Open reading frames (ORF) were also checked in the cloned sequences (Table IV). cDNA\#R presented the poly (T) tail at the 5' end of the reverse strand. Poly (A) tails are positioned at the 3' end of the RNA sequence. This indicates that the "minus" strand (the reverse complementary strand) of the reverse sequence is the sense strand, and the strand in which to look for ORFs. Five possible ORF may have occurred in cDNA\#R.

\section{Sequence homology search}

The forward sequence for cDNA\#R was analysed in the BLASTN GenBank and TIGR programmes because of its lower occurrence of ambiguous nucleotides compared with the reverse sequence. No attempts were made to replace the "N" nucleotides in the cloned sequences by any nucleotide to match its complementary sequence before being sent to the BLASTN and TIGR searches.

BLASTN and TIGR searches revealed that cDNA\#R did not have identity with known DNA sequences in the databases, although the cloned sequences did show some ho- mology with some database sequences. Three database sequences from the GenBank database were found to have short homology with the cDNA\#R sequence. Two database sequences belonged to the same family: metalloproteaselike, disintegrin-like proteins IVb and IVc. The PROSITE analysis of these database sequences homologous with cDNA\#R did not detect any protein sites or signatures within the homologous region. No matches were found for cDNA\#R in the TIGR database.

\section{DISCUSSION}

The DD technique was used in this experiment since it allows the identification of non-polymorphic genes through side-by-side comparisons between groups of animals having the same phenotypic characteristics, as well as for the identification of polymorphic genes.

Despite most of the reported differential display experiments having targeted two populations of cultured cells (Liang and Pardee, 1992; Liang et al., 992, 1993; Sager et al., 1993; Zimmermann and Schultz, 1994; Donohue et al., 1995; Wang and Feuerstein, 1995), tissue comparisons involving multicellular structures have been published with positive results (Utans et al., 1994).

The strategy used to maximise the chances of observing group-related differences was to compare groups of animals with extremely low- and high-YPC score breeding values (resistant vs. susceptible). This approach has been described by Tanksley (1993) as the "distributional extremes method", which assumes that individuals in the extreme tails of the Gaussian distribution (i.e., the lowest and the highest breeding values for a particular trait) are more likely to express differences in genotypes.

The use of sheep with extremes of YPC score breeding values also made it possible to reduce the number of animals to be screened in the current study. In this particular case the use of sheep with extreme YPC scores also avoided the inclusion of animals with intermediate YPC values that could have resulted in difficulties in the interpretation of the results. The low number of sheep used in the current experiment was a consequence of the high cost of screening large populations for genetic markers.

The cDNA\#R cloned sequence found in this study showed to have short homology, but no identity, with 3 database sequences from the GenBank. The lack of identity between the database sequences and the cDNAs cloned here means that these cDNAs were unknown sequences. Nonetheless, the search in the GenBank database was important because it gave some indication of the possible biological function of the cloned cDNAs.

Interestingly, a group of proteins with similar physiological functions was observed amongst the sequences with short homologies found in GenBank searches. The three database DNA sequences found for cDNA\#R: mast cell function associated antigen (MAFA) (Guthmann et al., 1995), metalloprotease-like disintegrin-like IVb (Perry et 


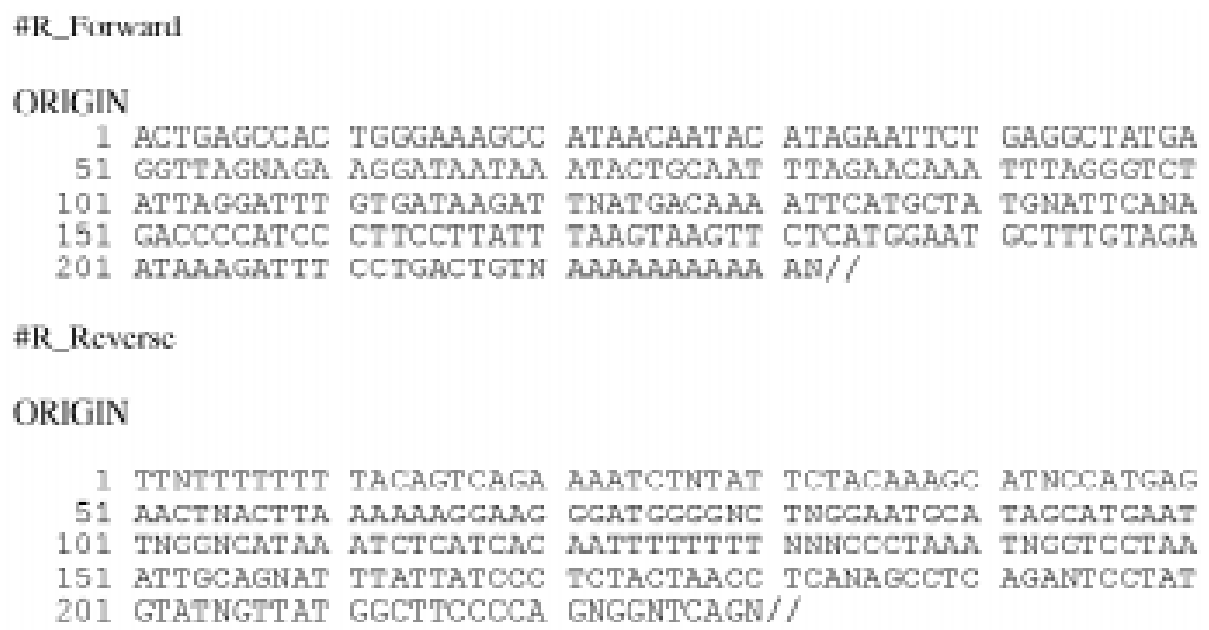

Figure 2 - Forward and reverse sequences of cDNA\#R.

Table IV - Regions where possible open reading frames (ORF) in cDNA\#R occur (forward: 1 to $232 \mathrm{bp}$ ). The table also shows the strand (plus or minus), number of amino acids present in each ORF and their respective position in the strand of the cDNA\#R sequences.

\begin{tabular}{|cccccc|}
\hline Strand & Frame & $\begin{array}{c}\text { Number of } \\
\text { amino acids }\end{array}$ & Position & $\begin{array}{c}\text { Start } \\
\text { codon }\end{array}$ & $\begin{array}{c}\text { Stop } \\
\text { codon }\end{array}$ \\
\hline Minus & 2 & 19 & $116-175$ & $\sqrt{ }$ & $\sqrt{ }$ \\
“ & 3 & 15 & $186-232$ & $\sqrt{ }$ & \\
“ & 1 & 11 & $1-36$ & & $\sqrt{ }$ \\
“ & 2 & 8 & $191-217$ & $\sqrt{ }$ & $\sqrt{ }$ \\
“ & 3 & 7 & $3-26$ & & $\sqrt{ }$ \\
\hline
\end{tabular}

al., 1995) and metalloprotease-like disintegrin-like IVc (Perry et al., 1995), have been reported to act in transmembrane signalling processes.

A possible link between proteins related to transmembrane functions and wool yellowing would be through the high potassium content in the sudoriparous glands secretion (suint) which has a strong positive phenotypic and genetic correlations with wool yellowing (Aitken et al., 1994; Benavides, 1997). Suint covers the wool follicle and if it has a high $\mathrm{pH}$ it may lead to an increase of wool yellowing (Acharya and Singh, 1976). A possible mechanism where $\mathrm{K}$ can be at higher levels in the sudoriparous gland cells is through the sodium-pump system, which actively transports $\mathrm{Na}^{+}$and $\mathrm{K}^{+}$ions across the cellular membrane through the action of the $\mathrm{Na}^{+}-\mathrm{K}^{+}$ ATPase enzyme (Sato and Dobson, 1970). Despite $\mathrm{Na}^{+}-$ $\mathrm{K}^{+}$-ATP being the main $\mathrm{K}^{+}$transport mechanism, it is not the only known system since $\mathrm{H}^{+}-\mathrm{K}^{+}$-ATPase also controls the exchange of $\mathrm{K}^{+}$from the plasma to the cells (Sachs et al., 1992). However, if there was a difference in $\mathrm{Na}^{+}-$ $\mathrm{K}^{+}$-ATPase between resistant and susceptible sheep it would most likely have been due to a difference in the activity of this essential enzyme. In this case, if $\mathrm{Na}^{+}-\mathrm{K}^{+}-$ ATP was the protein responsible for the higher $\mathrm{K}^{+}$content in the sweat glands in susceptible sheep a cDNA band would be seen simultaneously in both susceptibility groups, since it is a vital enzyme, but with different band intensity which could indicate a difference in gene expression between the two groups. At the time of this study it was not possible to draw any specific relationship between transmembranal functions or activity and wool yellowing susceptibility and the database sequences found to have homology with cDNA\#R in this experiment.

One way of better understanding the function of the cloned sequences would be to clone their corresponding full length cDNA. Amplification of partial sequences is a characteristic of the differential display technique because it uses oligo $\mathrm{d}(\mathrm{T})$ primers and amplification will not occur unless the arbitrary primer is situated within 2 to $3 \mathrm{~kb}$ of the oligo d(T) primer (Liang and Pardee, 1992). The fragments amplified in this experiment were relatively short, 1700 bp being the biggest fragment size, but $50 \%$ of the bands were $\leq 600 \mathrm{bp}$. The cloning of full length sequences would be necessary to confirm their identity with any known sequence.

Further confirmation of the differentially displayed cDNA\#R is essential to allow confidence in the use of this marker in order to identify sheep according to their degree of susceptibility. However, cDNA\#R would not be expected to identify $100 \%$ of resistant or susceptible sheep since this candidate gene was present in only four out of the five resistant sheep studied. This means that in practice not all resistant sheep will have been identified by the use of this probe. Wool yellowing is a continuous trait, therefore it might be affected by many genes; so, the failure of a single candidate gene for susceptibility to wool yellowing to explain all the genetic variance for this trait was an expected result. 


\section{CONCLUSIONS}

One differentially expressed band was found in the group resistant to wool yellowing with no identity with DNA sequences available at GenBank and TIGR databases. The differentially displayed sequence showed short homologies that might point at proteins with transmembrane signalling functions in the wool yellowing mechanism.

\section{ACKNOWLEDGMENTS}

We acknowledge the financial support of $\mathrm{CNPq}$ (Conselho Nacional de Desenvolvimento Científico e Tecnológico) and the help from Dr. José Carlos Ferrugem Moraes (Embrapa-CPPSUL) in the discussion of the results. We also would like to thank Messrs. Ross Wilson, Chris Logan from the Animal and Veterinary Sciences Group and Fraser Aitken, the laboratory staff of the Wool Measurement Service at Lincoln University, for the analysis and collection of the data, in particular Mrs. Jenny Nicol and Jill Sutton, and the laboratory staff of the Animal \& Veterinary Sciences Group, in particular Ms. Tania Gourley.

\section{RESUMO}

Ovinos resistentes e suscetíveis para predição da cor amarela na lã foram amostrados de um rebanho da raça Merino Australiano com o objetivo de comparar diferenças em cDNAs através da técnica de exposição diferencial de mRNA (differential display of mRNA). Uma banda de cDNA foi expressa somente no grupo dos animais resistentes. Não houve identidade desta banda com seqüências do banco de dados do GenBank ou TIGR, no entanto a banda chamada de cDNA\#R mostrou homologias curtas com três seqüências que codificam proteínas envolvidas em funções de membrana. $\mathrm{O}$ uso deste gene candidato como marcador genético de animais resistentes ao amarelamento necessita ser avaliado em rebanhos mais numerosos para confirmar os resultados.

\section{REFERENCES}

Acharya, R.M. and Singh, M. (1976). Canary coloration of wools: Breeds differences and their possible causes. Aust. J. Agric. Res. 27: 687-690.

Aitken, F.J., Cottle, D.J., Reid, T.C. and Wilkinson, B.R. (1994). Mineral and amino acid composition of wool from New Zealand Merino sheep differing in susceptibility to yellowing. Aust. J. Agric. Res. 45: 391401.

Altschul, S.F., Gish, W., Miller, W., Myers, E.W. and Lipman, D.J. (1990). Basic local alignment search tool. J. Mol. Biol. 215: 403-410.

Bairoch, A. (1993). The PROSITE dictionary of sites and patterns in proteins, its current status. Nucleic Acids Res. 21: 3097-3103.

Benavides, M.V. (1997). Investigation of indirect selection criteria and DNA markers for clean wool colour in sheep. PhD thesis, Lincoln University, Canterbury, New Zealand.

DeMayo, F.J., Finegold, M.J., Hansen, T.N., Stanley, L.A., Smith, B. and
Bullock, D.W. (1991). Expression of SV40 T antigen under control of rabbit uteroglobin promoter in transgenic mice. Am. J. Physiol. 261: L70-L76.

Donohue, P.J., Alberts, G.F., Guo, Y. and Winkles, J.A. (1995). Identification by targeted differential display of an immediate early gene encoding a putative serine/threonine kinase. J. Biol. Chem. 270: 1035110357.

Guthmann, M.D., Tal, M. and Pecht, I. (1995). A secretion inhibitory signal transduction molecule on mast cells is another C-type lectin. Proc. Natl. Acad. Sci. USA 92: 9397-9401.

Johnson, D.L. and Thompson, R. (1995). Restricted maximum likelihood estimation of variance components for univariate animal models using sparse matrix techniques and average information. J. Dairy Sci. 78: 449-456.

Lander, E.S. and Botstein, D. (1989). Mapping Mendelian factors underlying quantitative traits using RFLP linkage maps. Genetics 121: 185-199.

Liang, P. and Pardee, A.B. (1992). Differential display of eukaryotic messenger RNA by means of the polymerase chain reaction. Science 257: 967-971.

Liang, P. and Pardee, A.B. (1994). Differential display of mRNA by PCR. In: Current Protocols in Molecular Biology (Ausubel, F.M., Brent, R., Kingston, R.E., Moore, D.D., Seidman, J.G., Smith, J.A. and Struhl, K., eds.). Greene Publishing Associated, Toronto.

Liang, P., Averboukh, L., Keyomarsi, K., Sager, R. and Pardee, A.B. (1992). Differential display and cloning of messenger RNAs from human breast cancer versus mammary epithelial cells. Cancer Res. 52: 6966-6968.

Liang, P., Averboukh, L. and Pardee, A.B. (1993). Distribution and cloning of eukaryotic mRNAs by means of differential display: refinements and optimization. Nucleic Acids Res. 21: 3269-3275.

Newton, C.R. and Graham, A. (1994). PCR. BIOS Scientific Publishers Limited, Oxford.

Perry, A.C.F., Jones, R. and Hall, L. (1995). Analysis of transcripts encoding novel members of the mammalian metalloprotease-like, disintegrinlike, cysteine-rich (MDC) protein family and their expression in reproductive and non-reproductive monkey tissues. Biochem. J. 312: 239244.

Sachs, G., Besaneon, M., Shin, J.M., Mercier, F., Munson, K. and Hersey, S. (1992). Structural aspects of the gastric H, K ATPase. J. Bioenerg. Biomembr. 24: 301-308.

Sager, R., Anisowicz, A., Neveu, M., Liang, P. and Sotiropoulou, G. (1993). Identification by differential display of alpha 6 integrin as a candidate tumor suppressor gene. FASEB J. 7: 964-970.

SAS/STAT (1990). User's Guide Version 6 (Fourth). SAS Institute Inc., Cary, NC.

Sato, K. and Dobson, R.L. (1970). Enzymatic basis for the active transport of sodium in the duct and secretory portion of the eccrine sweat gland. J. Invest. Dermat. 55: 53-56.

Tanksley, S.D. (1993). Mapping polygenes. Annu. Rev. Genet. 27: 205-233.

Utans, U., Liang, P., Wyner, L.R., Karnovsky, M.J. and Russell, M.E. (1994). Chronic cardiac rejection: Identification of five upregulated genes in transplanted hearts by differential mRNA display. Proc. Natl. Acad. Sci. USA 91: 6463-6467.

Wang, X. and Feuerstein, G.Z. (1995). Direct sequencing of DNA isolated from mRNA differential display. BioTechniques 18: 448-453.

Wilkinson, B.R. (1981). Studies on fleece yellowing. Part 1: Prediction of susceptibility to yellow discolouration in greasy fleeces. Wool Technol. Sheep Breed. 29: 169-174.

Zimmermann, J.W. and Schultz, R.M. (1994). Analysis of gene expression in the preimplantation mouse embryo: Use of mRNA differential display. Proc. Natl. Acad. Sci USA 91: 5456-5460.

(Received February 21, 2000) 